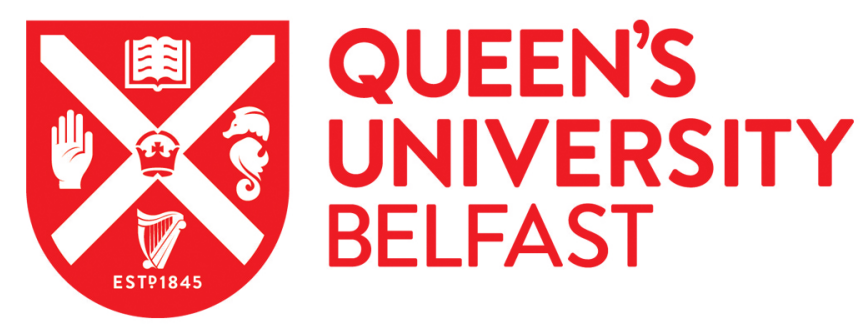

\title{
Using cooperative learning to close the reading attainment gap for students with low literacy levels for Grade 8/Year 9 students
}

Thurston, A., Cockerill, M., \& Craig, N. (2019). Using cooperative learning to close the reading attainment gap for students with low literacy levels for Grade 8/Year 9 students. International Journal of Educational Research, 94. https://doi.org/10.1016/j.ijer.2019.02.016

Published in:

International Journal of Educational Research

Document Version:

Peer reviewed version

Queen's University Belfast - Research Portal:

Link to publication record in Queen's University Belfast Research Portal

Publisher rights

Copyright 2019 Elsevier Ltd.

This manuscript is distributed under a Creative Commons Attribution-NonCommercial-NoDerivs License

(https://creativecommons.org/licenses/by-nc-nd/4.0/), which permits distribution and reproduction for non-commercial purposes, provided thjavascript:void(0);e author and source are cited.

\section{General rights}

Copyright for the publications made accessible via the Queen's University Belfast Research Portal is retained by the author(s) and / or other copyright owners and it is a condition of accessing these publications that users recognise and abide by the legal requirements associated with these rights.

Take down policy

The Research Portal is Queen's institutional repository that provides access to Queen's research output. Every effort has been made to ensure that content in the Research Portal does not infringe any person's rights, or applicable UK laws. If you discover content in the Research Portal that you believe breaches copyright or violates any law, please contact openaccess@qub.ac.uk. 
Using cooperative learning to close the reading attainment gap for students with low literacy levels for Grade 8/Year 9 students

Authorship: Allen Thurston (Queen's University Belfast), Maria Cockerill (Queen's University Belfast)\& Nicole Craig (Queen's University Belfast)

Corresponding author: Allen Thurston, Cell: +447964916186, email: a.thurston@qub.ac.uk

Address: Centre for Evidence \& Social Innovation, Queen's University Belfast, 20 College Green, Belfast, BT71LN, United Kingdom.

\section{Acknowledgements and Statements of Funding}

Acknowledgement

This work was supported by a grant under the 'Literacy Catch Up Round' by Education Endowment Foundation. We would especially like to thank the young people and school personnel who participated in the study, without their time and commitment this research would not have been possible.

\section{Abstract}

A randomized controlled trial of peer tutoring was undertaken in 60 Grade 6/Year 7, and 60 Grade 8/Year 9 classrooms (1299 Grade 6/Year 7 students and 1275 Grade 8/Year 9 students). Grade 8/Year 9 students acted as reading tutors to Grade 6/Year 7 students. Reading attainment was measured with an independent commercially available standardized reading attainment test with two sub-scales, sentence completion and passage comprehension. Results of multi-level modeling indicated significant gains in sentence completion for students acting as tutors in the bottom decile of reading, with no gains, nor deficits observed in the sample as a whole.

\section{Background}

Piaget (1978) proposed that children developed understanding through the processes of assimilation and accommodation, associated with the construction of internal schemas for understanding the world. Piagetian based peer tutoring can provide the right balance between the disequilibrium caused through cognitive challenge and social exchanges between peers for effective learning to take place (Palinscar, 1998). Piagetian tutoring involves cognitive challenge from peers and post-interactive reflection and restructuring. Both tutor and tutee have to fulfill their roles effectively. This creates a social 
interdependence between tutor and tutee. Their individual success is linked through common goals and mutual dependence on each other for gains in the tutoring process to accrue. Without both tutor and tutee performing their roles in accordance with prescribed patterns for interaction, neither can gain benefit from the interaction. Theories underpinning social interaction during cooperative learning have been substantively developed and described by Social Interdependence Theory (Johnson, Johnson \& Roseth, 2010; Johnson \& Johnson 2012). For co-operative learning to be present during peer tutoring then social interdependence must be present in the form of:

- Goal structure (the pair work together with the aim of reading and understanding a piece of text)

- Positive interdependence (in the tutoring process clear patterns for interaction are defined in the roles of tutor and tutee)

- Individual accountability (both the tutor and tutee have responsibilities, in the form of tutoring used each must reflect in their own performance and the performance of their peer partner)

- Interaction patterns (the tutoring process is structured to stimulate promotive interaction, group processing and enhance social skills)

Thurston and Topping (2006) developed a theoretical model of cognitive development during cooperative learning in pairs building on the model presented by De Lisi and Golbeck (1999). Students read a text together. The tutor listens to the tutee read. They support the tutee by reading together with them on hard sections and after errors. In addition, the tutor will ask the tutee questions. Both of these processes require social interdependence (Johnson, Johnson \& Roseth, 2010) and processing of prior knowledge using metacognitive strategy to link previous learning to the current problem. This also facilitates self-regulation and should concomitantly result in enhanced metacognition as these two processes are interlinked (Eggen \& Kauchak, 1997). This may facilitate assimilation of the learning and accommodation of new ideas and of course new words. However, the accommodation does not imply long-term change at this point. Retaining the "correct" cognitive structure over time relies on the student gaining deeper understanding of the new cognitive structures leading to equilibration as a result of post-interactive reflection.

Peer tutoring is a structured form of cooperative learning characterized by specific role taking as either tutor or tutee. The reported study was a form of peer tutoring that focused on reading. In this technique students were paired, an older tutor with a younger tutee. Each had specific roles to play in the cooperative learning process. The tutee focused on reading text aloud. The tutor focused on error correction and asking appropriate questions to check the understanding of the tutee. It is widely reported to have beneficial effects 
on learning (Duran \& Monereo, 2005; Topping, 2001) and produced Effect Sizes of 0.2 in a previous RCT (Tymms et al., 2011). When paired reading is implemented with reasonably high implementation integrity, results are typically good (Duran \& Monereo, 2005; Topping, 1987; Topping \& Ehly, 1998). Paired reading focuses the contact and feedback from tutor to tutee on error correction (Topping, 2001). For optimal performance of paired reading there needs to be an attainment differential between tutors and tutees (Duran \& Monereo, 2005). Without the gap being correct, then both tutor and tutee can be under stimulated (Greenwood, Terry, Arreaga-Mayer \& Finney, 1992). In previous research low achieving tutees are reported to gain most from paired reading (Tudge \& Rogoff, 1989; Topping, 2001).

Co-operative or peer-assisted learning is widely reported to be an effective approach to learning and teaching in primary schools. A meta-analytic review of peer-assisted learning interventions with primary school students produced positive effect sizes indicating increases in achievement (unweighted mean ES $=0.59, S D=0.90$; weighted $E S, d=0.33, p<.0001,95 \%$ confidence interval $=0.29-0.37$ ). Effect sizes were strongest for studies with younger, urban, low income, ethnic minority students. In addition peer assisted learning that used interdependent reward schemes, ipsative evaluation and provided learners with more autonomy also had greater effect sizes (Rohrbeck, Ginsburg-Block, Fantuzzo \& Miller, 2003).

Co-operative paired reading is a form of co-operative learning/peer tutoring that involves the tutoring of a peer tutee by a tutor. In this process the tutor monitors and manages the performance of the tutee to promote development. Topping and Ehly (1998) provide a theoretical model as to how co-operative peer tutoring promotes cognitive gains. The model addresses organizational/structural features of the co-operative learning interaction, such as: maximizing time on/engaged with task; the need for tutor and tutee to elaborate goals/plans; the individualization of learning and immediacy of feedback; the excitement and variety of a different kind of learning interaction. In the model peer tutees receive support and scaffolding from a peer tutor, necessitating management of activities within the 'Zone of Proximal Development' (Vygotsky, 1978). The tutor acts as co-learner and any potential damaging excess of challenge is minimized. Tutors manage and modulate the information processing demands upon the learner. The tutor provides a cognitive model of competent performance. The cognitive demands upon the tutor are great. They have to monitor learner performance and detect, diagnose, correct and manage misconceptions/errors. Heavy demands are made upon the communication skills of peers in this relationship.

For the tutee a trusting relationship with a peer tutor who holds no position of authority might facilitate self-disclosure of ignorance/misconception. Trust is 
reported to be very important to allow learners to take risks and expose their learning and misconceptions to each other during co-operative learning (Lahno, 2001). This should facilitate diagnosis and correction. These sub-processes feed into a larger onward process of extending declarative knowledge, procedural skill, and conditional and selective application of knowledge and skills, by, adding to and extending current capabilities (accretion), modifying current capabilities (re-tuning), and rebuilding new understanding (restructuring in areas of completely new learning or cases of gross misconception) (Rumelhart \& Norman,1983). This should lead to the joint construction of a shared understanding between peers.

Peer tutoring might facilitate a greater volume of engaged and successful practice, leading to consolidation, fluency and automaticity of core skills. In particular this may occur for the tutor as they have to prepare and deliver teaching to the tutee (Thurston \& Topping, 2007). As this occurs, both tutor and tutee give feedback to each other. Spontaneous feedback that may be less focused on the actual outcomes of learning is likely to occur in the earlier stages. As the learning relationship develops, both tutor and tutee should begin to become more consciously aware of what is happening in their learning interaction, and consequently more able to monitor and regulate the effectiveness of their own learning strategies. This development into fully conscious explicit and strategic meta-cognition is likely to promote more effective onward learning. It should also make both tutor and tutee more confident that they can achieve even more, and that success is the result of their own efforts. The conclusion of this is that the process is not linear, but cyclical and represents a 'reflect and connect' process. The affective and cognitive outcomes feed back into the originating sub-processes to form a positive reinforcement loop.

Fixed role cross-age co-operative learning/peer tutoring has been shown to be effective in raising pupil achievement. One finding associated with cross-age tutoring reported by researchers is that, in the process of tutoring, tutors reinforce their own knowledge base and skills. That is, tutors learn the material thoroughly and in a way that is more easily remembered (Fitz-Gibbon, 1978). Results presented in previous meta-analyses of Randomized Controlled Trials (RCTs) of Peer Learning (Cohen, Kulik \& Kulik, 1982; Cook, Scruggs, Mastropieri \& Casto, 1986) showed positive ES in the range of 0.40 and 0.80 . Cohen et al. (1982) reported in a meta-analysis of 52 cross-age tutoring studies that tutors generally exhibited a small, but significant improvement in academic performance; they found the average ES for the tutors to be 0.33 . Tutoring effects were larger in more structured programs, and in tutoring programs of shorter duration. The effects were also larger when lower level skills were taught and tested on examinations. Effects were larger on locally developed tests and smaller on nationally standardized tests. In 33 of the 38 studies 
investigating effects in this area, students who served as tutors performed better in examinations than control students in the subject being taught.

The form of co-operative paired reading chosen as the subject of this study was characterized by specific role taking as tutor or tutee (fixed role, cross-age), with high focus on error correction and clear procedures for interaction, in which participants received training. The emphasis was on error correction and for this reason fixed role peer tutoring (in which tutors remain in that position within the pair) method was the most appropriate constellation for dyads. Untrained tutoring behaviours tend to be primitive (e.g., Person \& Graesser, 1999), characterized by infrequent correction of errors and giving of positive feedback when inappropriate. When paired reading is implemented with reasonably high implementation integrity in terms of following set error correction protocols, results are typically good (Duran \& Monereo, 2005; Topping, 1987; Topping \& Ehly, 1998). Paired reading focuses the contact and feedback from tutor to tutee on error correction (Topping, 2001). For optimal performance of paired reading where the emphasis is on error correction there needs to be an attainment differential between tutors and tutees (Duran \& Monereo, 2005). Without the gap being correct, then both tutor and tutee can be under stimulated (Greenwood, Terry, Arreaga-Mayer \& Finney, 1992). Low achieving tutees are reported to gain most from paired reading (Tudge \& Rogoff, 1989; Topping, 2001).

Paired reading is reported to be an effective way of raising reading attainment in both primary age students (Duran \& Monereo, 2005) and high school age students (Topping, 2001). Positive ES were reported for experimental classes in respect of number of words read correctly in reading aloud ( $E S=0.22)$, and number of questions answered correctly about passages read $(E S=0.55)$ in a study of paired reading in 20 experimental and 20 control schools. The study involved paired reading amongst nine and a half year-old students for 35 minutes per day, 3 days a week over a 15-week period (Fuchs, Fuchs, Mathes \& Simmons, 1997). Process observations have been reported to be an effective way of assessing implementation integrity in paired reading initiatives. In a 4 year study involving 33 control and 56 experimental students aged 7-10 years-old undertaking paired reading for 30 minutes per week process observations showed significant advantages for experimental students in reading aloud $(F(2,46)=21.26, p<0.001)$, academic talk $(F(2,46)=10.34$, $p<0.01$ ) and question asking $\mathrm{F}(2,46)=4.73, p<0.05)$ when compared to control students. Significantly better gains in reading attainment were also reported for experimental students $(F(2,175)=16.43, p<0.0001)$ (Greenwood, Delquadri \& Hall, 1989).

Co-operative interaction in structured reading activities can enhance reading comprehension and promote the use and development of self-regulation 
strategies (Alvermann \& Rush, 2004; Duke \& Pearson, 2002; Fuchs \& Fuchs, 2000). Almasi (1995) concluded that students who engaged in peer discussion were better able to recognize and resolve differences and incongruities on their own than control group students who had received teacher led discussion. It was concluded that traditional teacher led patterns of interaction namely, teacher poses question-student responds to question-teacher evaluates student response to question, were insufficient for the development of understanding of the meaning of text (Almassi, 2003). Discussions between peers provide opportunities for metacognitive exchanges and modeling (Palincsar, David, Winn, \& Stevens, 1991). Peer interaction and talk can promote self-regulation during reading where students have to take an active role in recognizing and overcoming their difficulties in understanding texts (Almasi, 1995; Duke \& Pearson, 2002). In a study of 32 fifth-grade students it was reported that co-operative learning using a think before reading, during reading and after reading' method, resulted in significant gains in oral reading comprehension for experimental students (Mason, 2004). An extensive review of peer learning literature reported that peer interaction during co-operative learning can include discussion around meaning of text, identification and correction of errors, discussion of response to text, and activities during which students implement, evaluate, and modify reading strategy (Mastropieri \& Scruggs, 1997). A recent systematic review of 142 primary education reading research studies that included randomized or matched control groups with a minimum of twelve-week duration found that $E S$ were very positive. 17 studies used cooperative learning/class-wide peer tutoring and weighted mean $E S$ for these studies was +0.46 (Slavin, Lake, Chambers, Cheung \& Davis, 2009). Despite the established relationships between peer interaction and enhanced reading comprehension, it is still reported that the activity is not widely utilized by teachers (Alverman, 2000).

Fixed role cross-age peer tutoring, with older more capable students tutoring younger and less capable students is reported to be an effective method of raising reading engagement and attainment. In a small-scale study it was shown to enhance positive learning interactions amongst socially rejected and isolated boys during a five-week trial (Gumpel \& Frank, 1999). Cross-age cooperative learning in reading with second and fifth graders was reported to enhance reading attainment in a quasi-experimental study involving 454 students from 19 schools in Belgium. Multi-level modeling revealed gains for cross-age pairings, but no significant gains for same-age pairings compared to control groups (Van Keer, 2004; Van Keer \& Verhaeghe, 2005). Oral reading with scaffolding from teachers and parents was demonstrated to be effective at raising oral and silent reading ability in a randomized study of 400 students in Grades 3-5 (Kim \& White, 2008).

\section{Aims and Objective}


Cooperative learning in the form of paired reading has been shown to be effective in primary school settings. A 129 school randomized controlled trial reported effect sizes of about 0.2 (Tymms et al., 2011). However, the use of the technique in high school has not been systematically tested. There are wellreported differences in school attainment in groups of students. These are often reported to be related to student background, with students from higher poverty backgrounds underperforming students from more affluent backgrounds. Those in the bottom decile of reading attainment have been described as being particularly resistant to interventions designed to raise school attainment (Hirsch, 2007). This has been referred to as the attainment gap. The aim of this research was to establish if cooperative learning in reading could help close the attainment gap between average to high literacy attainment and those with low literacy attainment, who tend to be from high poverty homes.

\section{Research questions}

1. What are the effects of cooperative learning in reading on reading attainment?

2. Are there benefits of cooperative learning on reading attainment in reading for students with low literacy levels (those in the bottom reading attainment decile)?

\section{Method}

Sample: Schools in a large urban local education authority in the north east of England were invited to express interest in the project via email. 11 schools expressed interest in the project, but prior to randomization one school withdrew due to an imminent Office for Standards in Education school inspection. Data was therefore collected from 60, Grade 6/Year 7 and 60, Grade 8/Year 9 classes drawn from 10 high school settings. Data is presented from 1299 Grade 6/Year 7 students (mean age 12.27 years) and 1275 Grade $8 /$ Year 9 students (mean age 14.27 years). Average school size was 880 (SD 364) students, average free school meal (FSM) percentage was $20.24 \%$ and average Action Plus/Statement of Special Educational Need (SEN) was $10.92 \%$. The bottom reading attainment decile had FSM of $32.00 \%$ (Grade $8 /$ Year $9,44.18 \%$ ) (showing it was composed of a higher proportion of high poverty children than any other decile) and $34.54 \%$ SEN (Grade $8 / Y$ Year 9 , $34.09 \%$ ), again considerably higher than any other decile. Grade $8 / Y$ Year 9 and Grade 6/Year 7 classes were paired on the basis of timetabling availability, and then assigned in pairs to intervention or control condition at the class level. This represented 1338 students randomized to control condition and 1236 randomised to receive the paired reading intervention. Retention rate pre to post test was $100 \%$ at the class level and $>99.99 \%$ at the student level (only 5 
students were missing from post-test data). Missing data was treated as missing at random, and estimated value for Standardised Assessment Score (SAS) were calculated by the NGRT algorithm using sections of the test that had been completed. This meant that the analysis was completed on a $100 \%$ school, class and student sample. Attrition was very low due to this being an electronic test, that could be completed once a student returned to school after illness, and the fact that the time between pre and post-test was about 8 months so not many students had left the school. The participant flow diagram is shown in Figure 1.

\section{INSERT FIGURE 1 HERE}

Reading attainment: Adaptive electronic independent attainment tests in reading were used at the request of the funder of this work. These tests were Granada Learning New Group Reading Test. The tests are internationally available, independently designed instrument with good reliability (Cronbach alpha $=0.846$ for 2574 students in this study). They measured two dimensions of reading: sentence completion and passage comprehension. These are combined to give an overall standardized reading age score, where 100 is the standardized score for the age of the child and 10 is one standard deviation from the norm.

Analysis: Multi-level modeling was used to analyse the effect of paired reading on the outcomes taking the class-level clustering into account. The analysis is conducted for each outcome with the whole sample. In addition, analyses are also undertaken with each year group, Grade 6/Year 7 (who were tutees in this intervention) and Grade 8/Year 9 (who acted as tutors in the intervention) and subgroup and finally, analyses are undertaken for those in the bottom decile in the Grade 6/Year 7 and Grade 8/Year 9 samples, as this was a particular focus of the intervention, as this work was funded as part of a 'literacy catch-up' funding programme.

Paired Reading technique: The Paired Reading technique involved switching between the tutor and tutee reading together and the tutee reading alone. The book chosen by pairs had to be above the independent readability level of the tutee, but below that of the tutor and appropriate to their interest. This facilitated the tutor helping the tutee through the error correction process. Readability level was decided by using a simple test. Tutees randomly selected twenty words from the book from four different pages. They did this by closing their eyes and placing their outstretched fingers on the book. They read the word underneath their fingers. If the tutee could read between thirteen and nineteen words the book was deemed to be at the right level of readability. Teachers also checked the appropriateness of readability of books during observations. The tutor and tutee started by reading together. The tutee signalled to read 
alone. Upon an error the tutor waited 4-5 seconds and if the tutee did not self correct, was corrected by the tutor. The tutee repeated the error word correctly and the pair read together again until the tutee signalled to read alone. The tutee read alone until the next error.

Matching of pairs: Pairs were matched on the basis of previous reading attainment. Students within classes were ordered from highest to lowest in reading attainment using the pre-test NGRT result. The top-attaining tutor in the older class tutored the top-attaining tutee in the younger class; the second top tutor tutored the second top tutee in the younger class, and so on. Once matched, the advice given to teachers was that pairs stayed together for the duration of the intervention period. At the beginning of the intervention period, teachers were allowed some latitude to switch pairs who were clearly not able to form a working partnership. These processes were adopted on the basis that previous research indicated that an attainment gap was preferable to optimise the interactions and benefit within pairs (Duran \& Moreneo, 2005). The matching technique was originally reported and described in some detail by Fuchs et al (1997). It had also been used for reading in the Fife Peer Learning study which used a similar technique with primary school students (Tymms et al., 2011).

A manual describing the technique used is available at: https://pure.qub.ac.uk/portal/en/activities/using-peer-tutoring-to-improvereading(81b742aa-17e7-4d20-b0b1-cc43c1d55a02).html

Continuing professional development (CPD) for teachers: Teachers attended two CPD sessions per year starting in November. The first day provided an overview of the techniques and research design. Demonstrations of the Paired Reading were given. A manual to support teachers was provided for each school. Finally, the teachers were allowed to forward plan and start to consider the issues that may arise for them when implementing the project. A second day in May focused on sharing successes with teachers and having teachers evaluate the project. All teachers attended these events which were offered on two different dates (repeated) to maximise attendance. Further support involved classroom visits and twilight meetings for clusters of schools. 60 teachers attended CPD day one and 52 attended CPD day two. In year two of the study a number of the teachers were continuing to teach the same classes.

Training of Pupils: Training videos were provided for the intervention classes. Videos were produced during the pilot study (Cockerill \& Thurston, 2015) and contained local students and teachers with local accents. Teachers were advised on how to model the techniques for students with another staff member. 
Length and duration of intervention: The intervention took place over a period of 8 months. This spanned a period from November to June in one school year. The intervention lasted for 15 weeks.

\section{Results}

Data presented in Tables 1 and 2 descriptive statistics for mean reading attainment for the sentence completion and passage comprehension subscales and calculated standardized reading age score at pre and post-test for intervention and control groups. No significant differences were detected between the mean standardized attainment score of intervention (98.98) and control (99.33) groups at pre-test $F(1,2720)=0.381, p=0.537$.

\section{INSERT TABLES 1 AND 2 HERE}

Data presented in Table 3 (Grade 6/Year 7) and Table 4 (Grade 8/Year 9) present the main multi-level models run for the study. The main model was a simple model of group status (intervention or control) and pretest covariate (Sentence Completion, Passage Comprehension and Age Standardized Assessment Score) Analyses indicated no significant effects of the intervention overall for Grade 6/Year 7 or Grade 8/Year 9 students. Similar models were run for the bottom decile of Grade 6/Year 7 and Grade 8/Year 9 students. This was because this was a 'literacy catch up' project with the aim of decreasing the gap between high and low attaining students. Data from the model for the bottom decile of Grade 8/Year 9 students is presented in Table 5.

\section{INSERT TABLES 3, 4 \& 5 HERE}

Analysis of data from the bottom decile of the sample (Table 5), indicated there was significant positive effect of Paired Reading on the sentence completion of Grade $8 /$ Year 9 students ( $E S=0.42$ ). This effect was statistically significant $(p<05)$. As this was the bottom decile of students in one-year group, there were 257 pupils across the 120 classes with an ICC of 0.9 included in this model. A post-hoc power analysis indicated actual power of $96 \%$ with this sample, based on alpha $=0.05$ to detect effects at $P<0.05$. The models for bottom decile of Grade 6/Year 7 students did not produce any notable significant positive or negative effects. They are not presented here due to their null results.

\section{Discussion and Conclusions}

This was a well-conducted properly scaled RCT of a cooperative learning technique that had been previously successful in primary school. There was not universal transfer of benefits to high school. The reason for this may have been two-fold. The Grade 6/Year 7 students when required in primary school 
received targeted reading interventions such as Reading Recovery. Grade 6/Year 7 students may have already had the benefits from a literacy catch up intervention that may have been possible. Effects of this intervention were similar, and so the Grade 6/Year 7 students may have already had the benefits of a similar intervention (Educational Endowment Foundation, 2018). It should be noted that the standard deviation on mean scores on each reading sub-scale is lower than for Grade 8/Year 9 and the ICCs for Grade 6/Year 7 classes are higher. Standardized reading age scores for Grade 6/Year 7 and Grade 8/Year 9 students were virtually identical (both were 8.29 years). This illustrates the fact that the Grade 6/Year 7 students had made comparatively better progress in primary school than the Grade 8/Year 9 students. This is a limitation of working in 'live' classrooms and schools. However, pragmatic randomized trials compare an intervention to 'treatment as usual'. It is not practical, and these authors would also argue potentially unethical, to create 'placebo' groups, or true 'controls'.

Conversely it should be noted that previous reports of the benefits of this technique in the primary school were undertaken without reference to a randomized controlled sample (Tymms et al., 2011). In this respect previous benefits of the technique in primary school may have been over-reported. This emphasizes the requirement for a control group in randomized trials to allow policy makers to make informed decisions about 'what works'. Researchers must take this into account when undertaking large-scale trials. Even if an intervention has worked in one context, a control group is necessary to determine effects of 'treatment as usual' in the sample being studied. That said, there was some evidence of positive effects in primary school with a matched comparison sample (Topping, Miller, Thurston, McGavock \& Conlin, 2011). Therefore, it may be more appropriate to think of paired reading as an intervention that is more effective in elementary/primary school as an early intervention.

Previous studies had predicted greatest gains using this cooperative learning technique for low attaining tutors (Tudge \& Rogoff, 1989; Topping, 2001). However, these reports were anecdotal. This study establishes in a scientific study that these benefits do accrue in that way for the sample of high school students. In this study it was low attaining tutors who showed the only significant gains. The level of cognitive demand on those acting as tutors is high. Inherent within the classroom organization of peer tutoring dyads there is often an embedded message about the status of students. Tutors are perceived as higher status than tutees (Sharan, 1980). Enhanced satisfaction with learning and achievement were reported in a sample of 104, twelve-year-old students in a reciprocal peer tutoring study. However, these gains were only evident when students were acting in the role of tutor (Rosen, Powell, Schubot \& Rollins, 1978). 
Tutors have previously been reported to experience more gains when undertaking paired reading. It was reported that during small quasiexperimental study of paired reading involving 294, 11 to 13-year-old students, taught by 12 teachers across three high schools, ES of gains for tutors were +0.24 and +0.26 on tests of passage comprehension and sentence completion respectively. Conversely, slight negative ES were reported for tutees of -0.09 for passage comprehension and -0.15 for sentence completion (Thurston, Cockerill, Craig \& Bersh, 2018). This may explain why it was tutors who showed benefit in a large-scale effectiveness trial. ES have been reported to be lower in randomized controlled trials with matching at pre-test, than quasiexperimental studies. As control classes were matched with intervention classes within the same school, and had non-significant differences in pre-test literacy scores, this would have fallen into a category where a lower effect size would have been expected (Zeneli, Thurston, A. \& Roseth, 2016). It also might explain why ES were smaller than those reported in the previous randomized trial of paired reading, which only had a matched control (Topping et al., 2011) and did not match at pre-test, rather it used true randomization to assign to condition (Tymms et al., 2011).

The technique did not prove to be generalizable to high school students. However, it did provide significant gains to Grade 8/Year 9 students acting as tutors. Therefore, the technique shows promise as something that can close some aspects of the attainment gap for students with low literacy from high poverty backgrounds. Students in the Grade $8 / Y$ ear 9 bottom decile had a mean standardized reading age of 6.4 years as compared to a mean chronological age of 14.22 years. Therefore, their reading ages were still akin to those that may be typically found in primary school. This may be why they were the only group that could still benefit from using the technique.

The question as to why only sentence completion showed positive a ES on test scores does need to be addressed. This is likely to be a function of the length of the intervention. Figure 2 shows a logic model for the paired reading process. In this, the most immediate outcome would be more reading being undertaken and more new words being learned. This could be expected to be the immediate outcome of an error correction-based process. The more complex metacognitive understanding of text would be more likely to develop over a longer time period that was available to the intervention. As the intervention took place in schools with high poverty rates then one might expect that the ability to make gains in metacognitve awareness of text would come more slowly to students from lower socio-economic status homes, and therefore the longer term outcomes of the project were unlikely to have been optimized between pre/post test time periods (Hart \& Risley, 1995). 
Schools planning to implement the technique would have to decide whether; benefits would still accrue if this were a targeted intervention for Grade 8/Year 9 students in the bottom decile of reading attainment; or whether the benefits to this technique to a vulnerable sub-group and the lack of negative effects on other students make it worth implementing the technique as a whole school program. However, the severe depression of reading age in this group of high poverty, high SEN, bottom literacy decile students might prompt some schools to decide that this effort may be worth it. These students were less than twoyears from leaving formal education by the end of this intervention, and had effectively made only one year, four months of reading development during the nine years that they had spent in school. They are an exceptionally vulnerable group. The effect sizes reported in this study would represent about 6 months of reading development, although such conversions are problematic (Higgins et al., 2011). However, if these conversions were correct then it could be argued that the 16-week duration of this project may account for nearly $25 \%$ of their school-based reading development during their nine years of compulsory schooling. This is not an insignificant amount, and despite the time and effort of organizing such an intervention, schools may decide that it is worth it to benefit these hard to reach students and 'close the attainment gap', albeit slightly.

\section{$\underline{\text { References }}$}

Almasi, J. F. (1995). The nature of fourth graders' sociocognitive conflicts in peer-led and teacher-led discussion of literature. Reading Research Quarterly, 30, 314-351.

Almassi, J.F. (2003). Teaching strategic processes in reading, Guilford Press: New York.

Alvermann, D. E. (2000). Classroom talk about texts: Is it dear, cheap or a bargain at any price? In B. M. Taylor, M. F. Graves, \& P. Van Den Broek (Eds.), Reading for meaning. Fostering comprehension in the middle grades (pp. 170-192). New York: Teachers College Press.

Alvermann, D. E., \& Rush, L.S. (2004). Literacy intervention programs at the middle and high school levels. In T. L. Jetton \& J. A. Dole \& (Eds.). Handbook of Adolescent Literacy. New York: Guilford Press. Retrieved from: www.coe.uga.edu/lle/faculty/alvermann/intervention.pdf (30th January 2010).

Centre for Evaluation \& Monitoring (2009). About CEM. Available online at: www.cemcentre.org (accessed 16 November 2009).

Cohen, P. A., Kulik, J. A., \& Kulik, C. C. (1982). Educational outcomes of tutoring: a meta-analysis of findings, American Educational Research Journal, 19, 237-248 
Cook, S. B., Scruggs, T.E., Mastropieri, M.A., \& Casto, G.C. (1986). Handicapped students as tutors, The Journal of Special Education, 19, 483492.

De Lisi, R., \& Golbeck, S. L. (1999). Implication of Piaget's theory for peerlearning. In A. M. O'Donnell \& A. King (Eds.), Cognitive perspectives on peer-learning (pp 3-37). Mahwah, NJ: Erlbaum.

Department for Children, Schools \& Families (2009). Primary curriculum review. Available online at:

www.dcsf.gov.uk/primarycurriculumreview/downloads/primary curriculum ex ecs summary.pdf ( accessed 12 September 2009).

Duke, N. K., \& Pearson, P.D. (2002). Effective practices for developing reading comprehension. In A.E. Farstrup, \& S.J. Samuels (Eds.), What research has to say about reading instruction (pp. 205-242). New York: The Guilford Press.

Duran, D., \& Monereo, C.(2005). Styles and sequence of cooperative interaction in fixed and reciprocal peer tutoring, Learning \& Instruction, 15,179-199.

Educational Endowment Foundation (2018). Switch-on reading. Retrieved from: $\quad$ https://educationendowmentfoundation.org.uk/projects-andevaluation/projects/switch-on-reading/\#search (25 July 2018).

Eggen, P., \& Kauchak, D. (1997). Educational psychology: Windows on the classroom ( $3^{\text {rd }}$ ed.). Upper Saddle River, NJ: Prentice Hall.

Fitz-Gibbon, C. T., (1978). Setting up evaluating tutoring projects. Los Angeles, CA: Center for the Study of Evaluation, University of California.

Fuchs, D., Fuchs, L.S., Mathes, P.G., \& Simmons, D.C. (1997). Peer-assisted learning strategies: Making classrooms more responsive to diversity, American Educational Research Journal, 34, 174-206.

Fuchs, L. S., \& Fuchs, D. (2000). Building student capacity to work productively during peer-assisted reading activities. In B. M. Taylor, M. F. Graves, \& P. Van Den Broek (Eds.), Reading for meaning. Fostering comprehension in the middle grades (pp. 95-115). New York: Teachers College Press.

Greenwood, C. R., Delquadri, J.C. \& Hall, R.V. (1989). Longitudinal effects of classwide peer tutoring, Journal of Educational Psychology, 81, 371-383.

Greenwood, C. R., Terry, B., Arreaga-Mayer, C., \& Finnay, R. (1992). The classwide peer tutoring program: Implementation factors moderating student's achievement, Journal of Applied Behavior Analysis, 25,101-116.

Gumpel, T. P., \& Frank, R. (1999). An expansion of the peer tutoring paradigm: Cross-age peer tutoring of social skills among socially rejected boys. Journal of Applied Behavior Analysis, 32, 115-118.

Hamblin, J.A. \& Hamblin, R.L. (1972) On teaching disadvantaged preschoolers to read: A successful experiment, American Educational Research Journal, 9(2), 209-216. 
Hart, B., \& Risley, T. R. (1995). Meaningful differences in the everyday experience of young American children. Baltimore, MD: Paul H. Brookes Publishing Company.

Hayden, J. (2005). Profiles: Hayden Elementary School. Retrieved from: http://www2.ed.gov/programs/nclbbrs/2005/profiles/hayden.pdf $\quad$ (20th January 2010).

Heath, N. L., \& Glen, T. (2005). Positive illusory bias and the self-protective hypothesis in children with learning disabilities, Journal of Clinical Child and Adolescent Psychology, 34, 272-281.

Higgins S, Hall E, Baumfield V, Moseley D (2005) A meta-analysis of the impact of the implementation of thinking skills approaches on pupils. In: Research Evidence in Education Library. London: EPPI-Centre, Social Science Research Unit, Institute of Education, University of London.

Higgins, S., Kotosaki, D. \& Coe, R. (2011). Toolkit of strategies to improve learning. Summary for schools spending the pupil premium. http://www.suttontrust.com/research/toolkit-of-strategies-to-improvelearning/

Hirsch, D. (2007). Experiences of poverty and educational disadvantage. York, UK: Joseph Rowntree Foundation.

Johnson, D.W., Johnson, R.T., \& Roseth, C. (2010). Cooperative learning in middle schools: interrelationship of relationships and achievement. Middle Grades Research Journal, 5(1), 1-18.

Johnson, D.W., Johnson, R.T. (2012). Restorative Justice in the Classroom: Necessary Roles of Cooperative Context, Constructive Conflict, and Civic Values. Negotiation and Conflict Management Research, 5, (1), 4-28.

Kim, J. S., \& White, T.G. (2008). Scaffolding voluntary summer reading for children in grades 3 to 5: An experimental study, Scientific Studies of Reading, 12, $1-23$.

Lahno, B. (2001). On the emotional character of trust, Ethical Theory and Moral Practice, 4, 171-189

Learning \& Teaching Scotland (2000). Structure and balance of the curriculum 5-14 national guidelines. Available online at:

www.Itscotland.org.uk/Images/guidelinessaboc tcm4-122424.pdf (accessed 27 January 2010).

Learning \& Teaching Scotland (2008). About AifL-Assessment is for learning. Available online at: www.Itscotland.org.uk/assess/about/index.asp (accessed 11 September 2009).

Learning \& Teaching Scotland (2009). Interdisciplinary learning. Available online at:

www.Itscotland.org.uk/curriculumforexcellence/curriculumoverview/totality/i nterdisciplinary/index.asp (12th September 2009).

Mason, L. (2004). Explicit self-regulated strategy development versus reciprocal questioning: effects on expository reading comprehension among struggling readers. Journal of Educational Psychology, 96, 283-296. 
Mastropieri, M. A., \& Scruggs, T.E. (1997). Best practices in promoting reading comprehension in students with learning disabilities. Remedial \& Special Education, 18, 197-214.

Merrell, C. (2005). Personal communication. [date: $25^{\text {th }}$ May 2005]

National Reading Panel (2000). Teaching children to read: An evidence-based assessment of the scientific research literature on reading and its implications for reading instruction. Retrieved from www.nichd.nih.gov/publications/nrp/upload/smallbook pdf.pdf $\quad$ (20th January 2010).

Palincsar, A. S., David, Y. M., Winn, J. A., \& Stevens, D. D. (1991). Examining the context of strategy instruction. Remedial and Special Education, 12, 4353.

Palinscar, A. S. (1998). Social constructivist perspectives on teaching and learning. Annual Review of Psychology, 49, 345-375.

Piaget, J. (1978). The development of thought: Equilibration of cognitive structures. Oxford, UK: Basil Blackwell.

Person, N. K., \& Graesser, A. G. (1999). Evolution of discourse during crossage tutoring., in A.M. O'Donnell \& A. King (Eds.), Cognitive perspectives on peer learning (pp. 69-86). (Mahwah, NJ: Lawrence Erlbaum).

Qualification and Curriculum Development Agency (2007). The 10 principals: Assessment for learning. Available online at: www.qcda.gov.uk/4336.aspx (accessed 11 September 2009).

Rumelhart, D. E., \& Norman, D. A. (1983). Representation in memory. San Diego, CA: Center for Human Information Processing, University of California.

Rohrbeck, C. A., Ginsburg-Block, M. D., Fantuzzo, J. W., \& Miller, T. R. (2003). Peer-assisted learning interventions with elementary school students: A meta-analytic review, Journal of Educational Psychology, 95,240-257.

Rosen, S., Powell, E.R., Schubot, D.B. \& Rollins, P. (1978). Competence and tutorial role as status variables affecting peer-tutoring outcomes in public school settings. Journal of Educational Psychology, 70, 602-612.

Scoble, J., Topping, K., \& Wigglesworth , C. (1988). Training family and friends as adult literacy tutors. Journal of Reading, 31, 410-417.

Scottish Government (2004). Seventh survey of mathematics 2004. Retrieved from: http://www.scotland.gov.uk/Publications/2005/10/2192247/22532 8 June 2010)

Sharan, S. (1980). Cooperative learning in small groups: Recent methods and effects on achievement, attitudes, and ethnic relations. Review of Educational Research. 50, 241-271.

Slavin, R. E. (2008). Effects of sample size on effect size in systematic reviews in education. Paper present at the Randomised Controlled Trials in the Social Sciences: Methods and Synthesis Third Annual Conference York Sept/Oct 2008. 
Slavin, R. E., Lake, C., Chambers, B., Cheung, A., \& Davis, S. (2009). Effective reading programs for the elementary grades: A best evidence synthesis. Review of Educational research, 79, 1391-1466.

Slavin, R. E., \& Madden, N. A. (2000). Research on achievement outcomes of Success for All: A summary and response to critics. Phi Delta Kappan, 8 , 38-40, 59-66.

Stringer, W., \& Heath, N.L. (2008). Academic self-perception and its relationship to academic performance, Canadian Journal of Education, 31, 327-345.

Success for All Foundation (2008). Summary of research of the Success for All reading programs. Retrieved from:

www.successforall.net/ images/pdfs/410055000 SummResearch.pdf

(15th December 2009).

Thurston, A., Cockerill, M., Craig, N., \& Bersh, L. (2018). Assessing the differential effects of peer tutoring for tutors and tutees. Paper presented at the American Educational Research Association Annual Gathering, April 2018, New York.

Thurston, A., \& Topping, K.J. (2007). Peer tutoring in schools: Cognitive models and organisational typography, Journal of Cognitive Educational Psychology, 6, 356-372.

Topping, K. J. (1987). Peer tutored paired reading: Outcome data from ten projects, Educational Psychology, 7, 133-45.

Topping, K. J. (2001). Peer assisted learning: A practical guide for teachers. Cambridge MA: Brookline Books.

Topping, K. J., \& Ehly, S. (Eds.). (1998). Peer-assisted learning. Mahwah NJ \& London UK: Lawrence Erlbaum.

Topping, K.J., Kearney, M., McGee, E. \&, J. (2004). Tutoring in mathematics: A generic method. Mentoring and Tutoring, 12, 351-368.

Topping, K.J., Miller, D., Thurston, A., McGavock, K., \& Conlin, N. (2011). Peer tutoring in reading in Scotland: thinking big. Literacy, 45(1), 3-9.

Tudge, J. R. H., \& Rogoff, B. (1989). Peer influences on cognitive development: Piagetian and Vygotskyan perspectives., in M. Bornstein \& J.S. Bruner (Eds.). Interactions in human development (pp 17-40). Mahwah NJ \& London UK: Lawrence Erlbaum.

Tymms, P., Merrell, C., Andor, J., Topping, K.J., \& Thurston, A. (2009). Improving attainment across a whole district: peer tutoring in a randomised controlled trial. European Association of Research on Learning \& Instruction Amsterdam 24th-30th August 2009.

Tymms, P., Merrell, C., Thurston, A., Andor, J., Topping, K., \& Miller, D., (2011). Improving attainment across a whole district: school reform through peer tutoring in a randomized controlled trial. School Effectiveness and School Improvement, 22(3), 265-289. 
US Department of Education (2002). Scientifically based research and the Comprehensive School Reform (CSR) Program. Washington, DC: US Department of Education, Office of Elementary and Secondary Education.

US Department of Education (2006). Reading first implementation evaluation: Interim report. Washington, DC: U.S. Department of Education, Office of Planning, Evaluation and Policy Development, Policy and Program Studies Service.

U.S. Department of Education (2008). Creating and Sustaining Successful K8 Magnet Schools. Washington, DC.: U.S. Department of Education, Office of Innovation and Improvement.

Van Keer, H. (2004). Fostering reading comprehension in fifth grade by explicit instruction in reading strategies and peer tutoring. British Journal of Educational Psychology, 74, 37-70.

Van Keer, H., \& Verhaeghe, J. P. (2005). Effects of explicit reading strategies instruction and peer tutoring in second and fifth graders' reading comprehension and self-efficacy perceptions. The Journal of Experimental Education, 73, 291-329.

Vondra, J., Barnett, D., \& Cicchetti, D. (1989). Perceived and actual competence among maltreated and comparison school children, Development and Psychopathology, 1:237-255

Vygotsky L. S. (1978). Mind in society: The development of higher psychological processes. Cambridge M.A.: Harvard University Press.

Welsh Assembly Government (2005). Developing thinking and assessment for learning: development programme. Available online at: wales.gov.uk/topics/educationandskills/curriculumassessment/thinkingand assessmentforlearning/?lang=en (accessed 11 September 2009).

Welsh Assembly Government (2008). Making the most of learning: Implementing the revised curriculum. Available online at: wales.gov.uk/dcells/publications/curriculum and assessment/arevisedcurr iculumforwales/nationalcurriculum/makingthemostoflearningnc/Making Sta ndard WEB (E).pdf?lang=en

Zeneli, M., Thurston, A. \& Roseth, C. (2016). The influence of experimental design on the magnitude of the effect size -peer tutoring for elementary, middle and high school settings: a meta-analysis. International Journal of Educational Research. 76, 211-223.

Table 1: Mean pre-post test scores for Grade 6/Year 7

\begin{tabular}{|l|l|l|l|l|l|l|l|l|}
\hline Outcomes & \multicolumn{2}{|l|}{ Pre-test } & \multicolumn{2}{l|}{ Post-test } \\
\cline { 2 - 8 } & \multicolumn{2}{|l|}{ Intervention } & \multicolumn{2}{l|}{ Control } & \multicolumn{2}{l|}{ Intervention } & \multicolumn{2}{l|}{ Control } \\
\cline { 2 - 8 } & $\mathrm{n}$ & $\begin{array}{l}\text { Mean } \\
(\mathrm{SD})\end{array}$ & $\mathrm{n}$ & $\begin{array}{l}\text { Mean } \\
\text { (SD) }\end{array}$ & $\mathrm{n}$ & $\begin{array}{l}\text { Mean } \\
(\mathrm{SD})\end{array}$ & $\mathrm{n}$ & $\begin{array}{l}\text { Mean } \\
(\mathrm{SD})\end{array}$ \\
\hline
\end{tabular}




\begin{tabular}{|c|c|c|c|c|c|c|c|c|}
\hline $\begin{array}{l}\text { Sentence } \\
\text { Completion }\end{array}$ & 617 & $\begin{array}{l}328.52 \\
(46.08)\end{array}$ & 682 & $\begin{array}{l}331.91 \\
(46.55)\end{array}$ & 617 & $\begin{array}{l}340.26 \\
(49.57)\end{array}$ & 682 & $\begin{array}{l}345.41 \\
(50.11)\end{array}$ \\
\hline $\begin{array}{l}\text { Passage } \\
\text { Comprehensio } \\
n\end{array}$ & 616 & $\begin{array}{l}323.69 \\
(59.62)\end{array}$ & 681 & $\begin{array}{l}325.60 \\
(57.65)\end{array}$ & 615 & $\begin{array}{l}337.19 \\
(60.59)\end{array}$ & 681 & $\begin{array}{l}339.15 \\
(60.68)\end{array}$ \\
\hline $\begin{array}{l}\text { Age } \\
\text { Standardized } \\
\text { Assessment } \\
\text { Score }\end{array}$ & 617 & $\begin{array}{l}99.15 \\
(14.55)\end{array}$ & 682 & $\begin{array}{l}99.78 \\
(14.52)\end{array}$ & 617 & $\begin{array}{l}99.70 \\
(15.69)\end{array}$ & 682 & $\begin{array}{l}100.67 \\
(15.58)\end{array}$ \\
\hline
\end{tabular}

Table 2: Mean pre-post test scores for Grade 8/Year 9

\begin{tabular}{|c|c|c|c|c|c|c|c|c|}
\hline \multirow[t]{3}{*}{ Outcomes } & \multicolumn{4}{|c|}{ Pre-test } & \multicolumn{4}{|c|}{ Post-test } \\
\hline & \multicolumn{2}{|c|}{ Intervention } & \multicolumn{2}{|c|}{ Control } & \multicolumn{2}{|c|}{ Intervention } & \multicolumn{2}{|c|}{ Control } \\
\hline & $\mathrm{n}$ & $\begin{array}{l}\text { Mean } \\
\text { (SD) }\end{array}$ & $\mathrm{n}$ & $\begin{array}{l}\text { Mean } \\
\text { (SD) }\end{array}$ & $\mathrm{n}$ & $\begin{array}{l}\text { Mean } \\
(\mathrm{SD})\end{array}$ & $\mathrm{n}$ & $\begin{array}{l}\text { Mean } \\
\text { (SD) }\end{array}$ \\
\hline $\begin{array}{l}\text { Sentence } \\
\text { Completion }\end{array}$ & 619 & $\begin{array}{l}354.56 \\
(50.39)\end{array}$ & 656 & $\begin{array}{l}358.71 \\
(47.77)\end{array}$ & 619 & $\begin{array}{l}367.54 \\
(58.99)\end{array}$ & 656 & $\begin{array}{l}371.98 \\
(55.10)\end{array}$ \\
\hline $\begin{array}{l}\text { Passage } \\
\text { Comprehension }\end{array}$ & 617 & $\begin{array}{l}350.02 \\
(55.27)\end{array}$ & 656 & $\begin{array}{l}352.25 \\
(58.70)\end{array}$ & 613 & $\begin{array}{l}355.30 \\
(64.75)\end{array}$ & 655 & $\begin{array}{l}361.94 \\
(67.53)\end{array}$ \\
\hline $\begin{array}{l}\text { Age } \\
\text { Standardized } \\
\text { Assessment } \\
\text { Score }\end{array}$ & 619 & $\begin{array}{l}98.96 \\
(14.38)\end{array}$ & 656 & $\begin{array}{l}100.00 \\
(14.74)\end{array}$ & 619 & $\begin{array}{l}98.69 \\
(16.41)\end{array}$ & 656 & $\begin{array}{l}100.61 \\
(16.42)\end{array}$ \\
\hline
\end{tabular}


Table 3: Main multi-level model Grade 6/Year $7 \mathrm{n}=1299$

\begin{tabular}{|c|c|c|c|c|c|c|}
\hline \multirow[t]{2}{*}{ Outcome } & $\begin{array}{l}\text { Post-test } \\
\text { adjusted } \\
\text { (SDs) }\end{array}$ & $\begin{array}{r}\text { scores } \\
\text { pre-test }\end{array}$ & \multirow[t]{2}{*}{ Sig. } & \multirow[t]{2}{*}{$\begin{array}{l}\text { Effect } \\
\text { size }\end{array}$} & \multirow[t]{2}{*}{$\begin{array}{l}95 \% \\
\text { C.I.s }\end{array}$} & \multirow[t]{2}{*}{$\begin{array}{l}\text { Intra-class } \\
\text { correlation }\end{array}$} \\
\hline & $\begin{array}{l}\text { Intervention } \\
\text { group }\end{array}$ & $\begin{array}{l}\text { Control } \\
\text { group }\end{array}$ & & & & \\
\hline $\begin{array}{l}\text { Sentence } \\
\text { Completion }\end{array}$ & $\begin{array}{l}341.45 \\
(112.80)\end{array}$ & $\begin{array}{l}343.89 \\
(106.56)\end{array}$ & .31 & -.02 & $\begin{array}{l}-.13 \\
.09\end{array}$ & . 17 \\
\hline $\begin{array}{l}\text { Passage } \\
\text { Comprehension }\end{array}$ & $\begin{array}{l}336.88 \\
(141.71)\end{array}$ & $\begin{array}{l}337.59 \\
(146.49)\end{array}$ & .83 & .00 & $\begin{array}{l}-.11 \\
.10\end{array}$ & .21 \\
\hline
\end{tabular}

Table 4: Main multi-level model Grade 8/Year $9 \mathrm{n}=1275$

\begin{tabular}{|l|lll|l|l|l|l|}
\hline \multirow{2}{*}{ Outcome } & $\begin{array}{l}\text { Post-test } \\
\text { adjusted by } \\
\text { (SDs) }\end{array}$ & $\begin{array}{r}\text { scores } \\
\text { pre-test }\end{array}$ & Sig. & $\begin{array}{l}\text { Effect } \\
\text { size }\end{array}$ & $\begin{array}{l}95 \% \\
\text { C.I.s }\end{array}$ & $\begin{array}{l}\text { Intra-class } \\
\text { correlation }\end{array}$ \\
\cline { 2 - 6 } & $\begin{array}{l}\text { Intervention } \\
\text { group }\end{array}$ & $\begin{array}{l}\text { Control } \\
\text { group }\end{array}$ & & & & \\
\hline $\begin{array}{l}\text { Sentence } \\
\text { Completion }\end{array}$ & $\begin{array}{l}369.34 \\
(85.68)\end{array}$ & $\begin{array}{l}370.25 \\
(82.99)\end{array}$ & .68 & -.01 & $\begin{array}{l}-.12, \\
.10\end{array}$ & .06 \\
\hline $\begin{array}{l}\text { Passage } \\
\text { Comprehension }\end{array}$ & $\begin{array}{l}355.35 \\
(143.06)\end{array}$ & $\begin{array}{l}360.14 \\
(131.95)\end{array}$ & .31 & -.03 & $\begin{array}{l}-.15, \\
.08\end{array}$ & .16 \\
\hline
\end{tabular}

Table 5: Multi-level models summary table (Grade 8/Year 9 bottom decile $\mathrm{n}=257$ )

\begin{tabular}{|c|c|c|c|c|c|c|}
\hline \multirow{2}{*}{ Outcome } & \multicolumn{2}{|c|}{$\begin{array}{l}\text { Post-test scores adjusted } \\
\text { by pre-test (SDs) }\end{array}$} & \multirow{2}{*}{ Sig. } & \multirow[t]{2}{*}{ Effect size } & \multirow{2}{*}{$\begin{array}{l}95 \% \\
\text { C.I.s }\end{array}$} & \multirow{2}{*}{$\begin{array}{l}\text { Intra- } \\
\text { class } \\
\text { corre } \\
\text { ation }\end{array}$} \\
\hline & $\begin{array}{l}\text { Intervention } \\
\text { group }\end{array}$ & $\begin{array}{l}\text { Control } \\
\text { group }\end{array}$ & & & & \\
\hline $\begin{array}{l}\text { Sentence } \\
\text { Completion }\end{array}$ & $\begin{array}{l}303.37 \\
(58.97)\end{array}$ & $\begin{array}{l}276.23 \\
(69.58)\end{array}$ & .04 & .42 & $\begin{array}{l}-.01 \\
.85\end{array}$ & .09 \\
\hline $\begin{array}{l}\text { Passage } \\
\text { Comprehension }\end{array}$ & $\begin{array}{l}263.24 \\
(71.39) \\
\end{array}$ & $\begin{array}{l}264.62 \\
(63.27) \\
\end{array}$ & .91 & -.02 & $\begin{array}{l}-.46, \\
.42\end{array}$ & .05 \\
\hline
\end{tabular}


Figure 1: Participant flow diagram

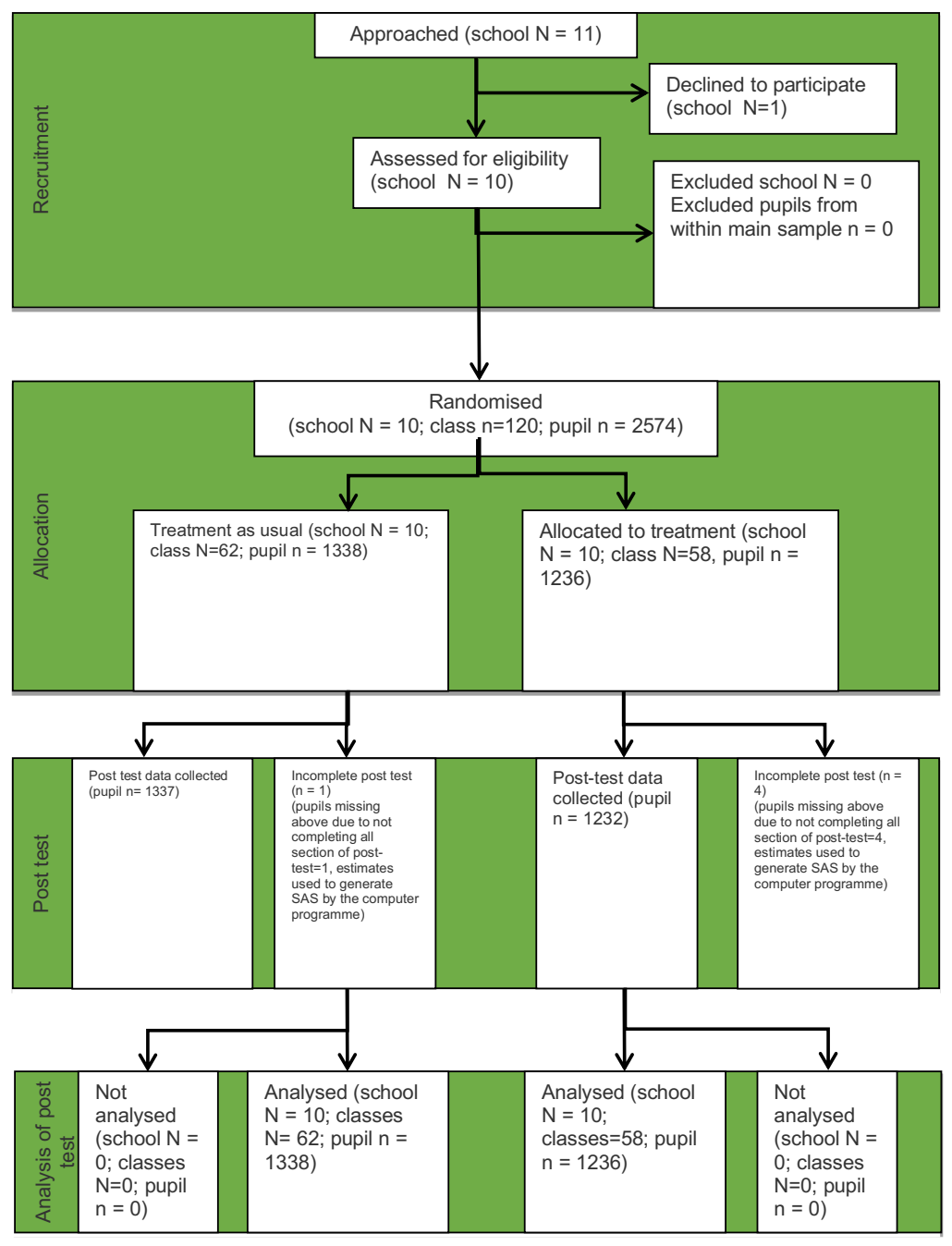


Figure 2: Logic model of the paired reading intervention

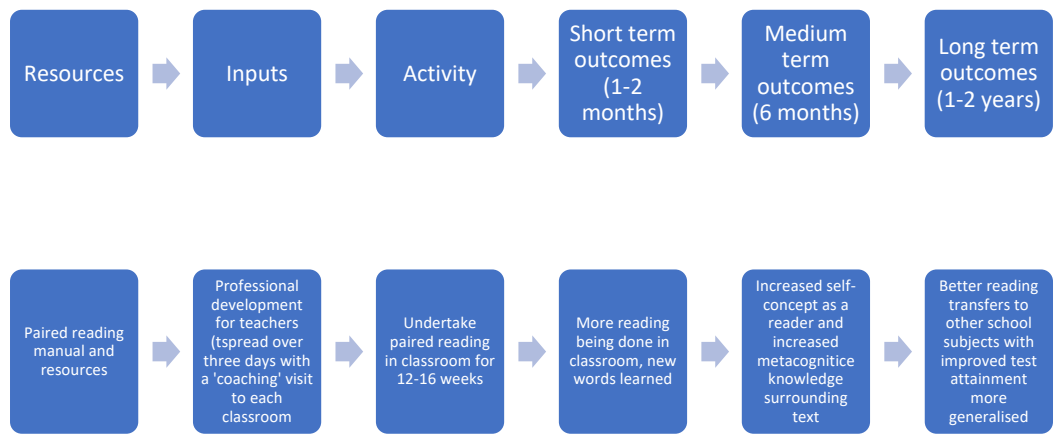

